\title{
Marker Assisted Development and Characterization of Herbicide Tolerant Near Isogenic Lines of a Mega Basmati Rice Variety, "Pusa Basmati 1121"
}

Nitasha Grover ${ }^{1,2}$, Aruna Kumar², Ashutosh Kumar Yadav1, S. Gopala Krishnan', Ranjith Kumar Ellur', Prolay Kumar Bhowmick', K. K. Vinod ${ }^{1}$, Haritha Bollinedi', M. Nagarajan ${ }^{3}$, C. Viswanathan ${ }^{4}$, Amitha Mithra V. Sevanthi ${ }^{5}$, Nagendra Kumar Singh ${ }^{5}$, Trilochan Mohapatra ${ }^{6}$ and Ashok Kumar Singh ${ }^{1^{*}}$ (D)

\begin{abstract}
Background: Direct-seeded rice (DSR) is a potential technology for sustainable rice farming as it saves water and labor. However, higher incidence of weed under DSR limits productivity. Therefore, there is a need to develop herbicide tolerant $(\mathrm{HT})$ rice varieties.

Results: We used marker assisted backcross breeding (MABB) to transfer a mutant allele of Acetohydroxy acid synthase (AHAS) gene, which confers tolerance to imidazolinone group of herbicides from the donor parent (DP) "Robin" into the genetic background of an elite popular Basmati rice variety, Pusa Basmati 1121 (PB 1121). Foreground selection was done using the AHAS gene linked Simple Sequence Repeat (SSR) marker RM6844 and background selection was performed using 112 genome-wide SSR markers polymorphic between PB 1121 and Robin. Phenotypic selection for agronomic, Basmati grain and cooking quality traits in each generation was carried out to improve the recovery of recurrent parent phenome (RPP). Finally, a set of $12 \mathrm{BC}_{4} \mathrm{~F}_{4}$ near isogenic lines (NILs), with recurrent parent genome (RPG) recovery ranging from 98.66 to $99.55 \%$ were developed and evaluated. PB 1121-HT NILs namely 1979-14-7-33-99-10, 1979-14-7-33-99-15 and 1979-14-7-33-99-66 were found superior to PB 1121 in yield with comparable grain and cooking quality traits and herbicide tolerance similar to Robin.

Conclusion: Overall, the present study reports successful development of HT NILs in the genetic background of popular Basmati rice variety, PB 1121 by introgression of mutated AHAS allele. This is the first report on the development of HT Basmati rice. Superior NILs are being evaluated in the national Basmati trials, the release of which is likely to provide a viable option for the adoption of DSR technology in Basmati rice cultivation.
\end{abstract}

Keywords: DSR, Marker assisted backcross breeding, AHAS, Herbicide tolerant, Foreground and background selection, Grain and cooking quality, Basmati rice

\footnotetext{
* Correspondence: aks_gene@yahoo.com

'Division of Genetics, ICAR-Indian Agricultural Research Institute, New Delhi

110012, India

Full list of author information is available at the end of the article
}

\section{Springer Open}

(c) The Author(s). 2020 Open Access This article is licensed under a Creative Commons Attribution 4.0 International License, which permits use, sharing, adaptation, distribution and reproduction in any medium or format, as long as you give appropriate credit to the original author(s) and the source, provide a link to the Creative Commons licence, and indicate if changes were made. The images or other third party material in this article are included in the article's Creative Commons licence, unless indicated otherwise in a credit line to the material. If material is not included in the article's Creative Commons licence and your intended use is not permitted by statutory regulation or exceeds the permitted use, you will need to obtain permission directly from the copyright holder. To view a copy of this licence, visit http://creativecommons.org/licenses/by/4.0/. 


\section{Background}

In South-East Asian countries, where rice is primarily cultivated by transplanting, DSR holds great promise as it is a potential water and labor saving technology, which offers the possibility of saving huge amount of water and labour needed for puddling and transplanting. However, DSR cultivation suffers from high weed infestation. Weeds pose a serious threat by competing with the crop for water, nutrients and light, thereby hampering productivity (Powles and Yu 2010). In India, upto 30\% of the total cost of rice cultivation goes in controlling weeds (Rao et al. 2015). It has been demonstrated that with effective weed management, the yields from DSR is widely comparable to transplanted rice (Pathak et al. 2011). The use of herbicides is the most effective and economical option to control weeds (Anderson and Georgeson 1989). However, the herbicides that are safe and effective at minimal doses should be used to ensure environmental safety. Imidazolinone group of herbicides (imazapyr, imazapic, imazethapyr, imazamox, imazamethabenz and imazaquin etc.), control weeds by inhibiting the enzyme acetohydroxyacid synthase (AHAS), also called acetolactate synthase (ALS). AHAS is a critical enzyme for the biosynthesis of branched-chain amino acids namely, leucine, isoleucine and valine in plants. These herbicides, also have low mammalian toxicity due to lack of $A H A S$ gene (Tan et al. 2006; Piao et al. 2018). Due to the above benefits, the herbicides of imidazolinone group are most widely used for weed control in crops like soybean, groundnut etc., which possess natural tolerance to these herbicides. However, the crops like rice, maize, wheat, oilseed rape and sunflower etc. are highly sensitive to imidazolinones. Several variants of AHAS genes conferring imidazolinone tolerance have been developed through mutagenesis and selection in different crops and commercialized as Clearfield ${ }^{\circ}$ crops

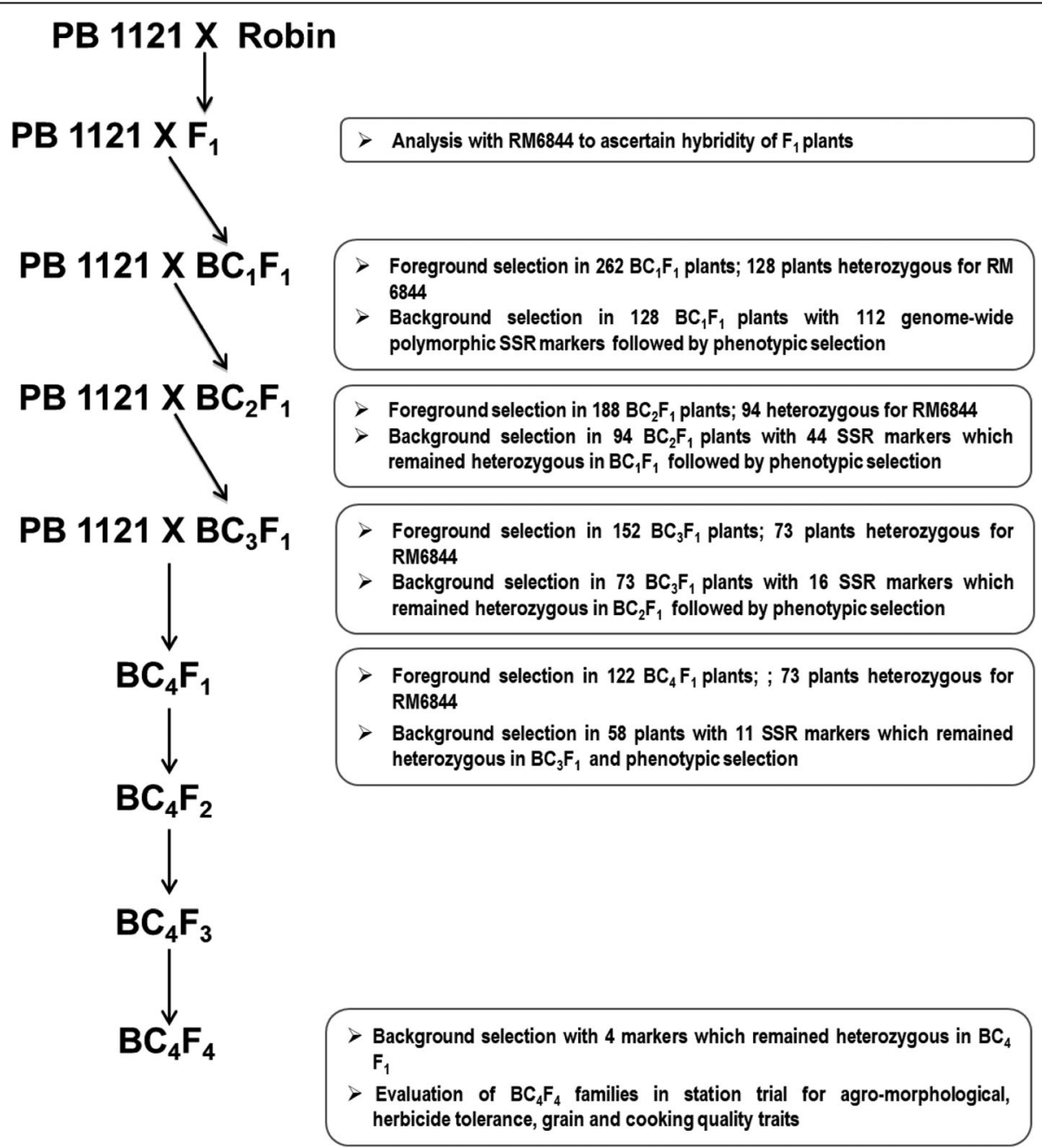

Fig. 1 Marker aided backcross breeding strategy used for transferring the herbicide tolerance trait into PB 1121 
Table 1 Details of SSR marker linked to the AHAS gene which was used in foreground selection

\begin{tabular}{lllrr}
\hline Marker & Primer Sequences & Tm & PB 1121 Allele & Robin Allele \\
\hline RM6844 & F: AGTCCAAGAAAGGCACGAGAGG & $58^{\circ} \mathrm{C}$ & $140 \mathrm{bp}$ & $200 \mathrm{bp}$ \\
& R: CTGCATCGAAGAAGAAGAAGAAGC & & & $1.2 \mathrm{~cm}$ \\
\hline
\end{tabular}

since 1992. Imidazolinone herbicides control a broad spectrum of grass and broadleaf weeds in imidazolinonetolerant crops, including weeds that are closely related to the crop itself and some key parasitic weeds (Tan et al. 2005).

Here, we report the transfer of mutant allele of $A H A S$ gene conferring herbicide tolerance from Robin into a mega Basmati rice variety, PB 1121, through MABB and assessment of PB 1121 NILs for agronomic, grain and cooking quality performance in addition to herbicide tolerance.

\section{Material and Methods \\ Plant Materials}

In this study, we used the herbicide tolerant rice mutant Robin as donor and a mega-Basmati rice variety, $\mathrm{PB}$ 1121 as the recurrent parent (RP) for the transfer of HT trait. The mutant Robin was developed from an upland rice variety Nagina 22 (N22) through induced mutagenesis using ethyl methane sulfonate (EMS) (Shoba et al. 2017). PB 1121, developed by our group at ICAR-Indian Agricultural Research Institute (IARI), New Delhi, is a Basmati rice variety par excellence in grain and cooking quality with an exceptionally high cooked kernel length $(22 \mathrm{~mm})$ and elongation ratio of $>2.5$. This variety is currently grown on approximately 1.2 million ha area ( $60 \%$ of the Basmati area in India) and contributes annually 3.41 billion USD to foreign exchange earnings through the export of Basmati rice (Singh et al. 2018b).

\section{MABB Strategy for Development of HT Lines}

PB 1121 and mutant Robin were first evaluated for their tolerance to the herbicide "Imazethapyr" at the dose of $2.5 \mathrm{ml} /$ litre. The $\mathrm{F}_{1}$ seeds were produced by crossing PB 1121 as female and Robin as male and the hybridity of the $\mathrm{F}_{1}$ plants was tested using the SSR marker RM6844 linked with $A H A S$ gene. The $\mathrm{F}_{1} \mathrm{~s}$ were designated as Pusa 1979 and single $F_{1}$ was backcrossed with $\mathrm{PB} 1121$ to generate $\mathrm{BC}_{1} \mathrm{~F}_{1}$ seeds. One $\mathrm{BC}_{1} \mathrm{~F}_{1}$ plant with the highest recovery of $\mathrm{RPG}$ and recurrent parent phenome (RPP) was backcrossed to $\mathrm{PB} 1121$ to generate the $\mathrm{BC}_{2} \mathrm{~F}_{1}$ seeds. A similar strategy was employed till $\mathrm{BC}_{4} \mathrm{~F}_{1}$ generation, wherein in each of the generations, the plant heterozygous for the mutant AHAS allele along with maximum recovery for RPG and RPP were identified. The superior
$\mathrm{BC}_{4} \mathrm{~F}_{1}$ plants were advanced to $\mathrm{BC}_{4} \mathrm{~F}_{2}$ generation and plants homozygous for the mutant AHAS allele were identified. Further, the selected $\mathrm{BC}_{4} \mathrm{~F}_{2}$ plants were advanced to $\mathrm{BC}_{4} \mathrm{~F}_{4}$ generation via pedigree-based phenotypic selection (Fig.1).

\section{Molecular Analysis}

Total genomic DNA from leaf tissues was extracted using Cetyl Trimethyl Ammonium Bromide (CTAB) method (Doyle 1991). The PCR reaction of a total $10 \mu \mathrm{l}$ volume was set up which included, 25-30 ng of template DNA, 5 pmol each of the forward and reverse primers and $2 \mathrm{X}$ red dye PCR master mix (Genei Laboratories Pvt. Ltd., Bangalore). The program of PCR amplification consisted of initial denaturation at $95^{\circ} \mathrm{C}$ for $5 \mathrm{~min}$; 35 cycles of denaturation at $95^{\circ} \mathrm{C}$ for 40 s, annealing at $58^{\circ} \mathrm{C}$ for 40 s, extension at $72^{\circ} \mathrm{C}$ for $1 \mathrm{~min}$; and a final extension at $72{ }^{\circ} \mathrm{C}$ for $10 \mathrm{~min}$. The amplified products were resolved on 3.5\% Metaphor ${ }^{\mathrm{TM}}$ Agarose gel mixed with $0.1 \mathrm{mg} / \mathrm{ml}$ ethidium bromide. The amplicons were visualized on ultraviolet trans-illuminator $\left(G^{2}\right.$ Doc $^{\mathrm{TM}}+$ Imager, Bio- Rad Laboratories Inc., U.S.A).

\section{Foreground and Background Selection}

Foreground selection for the identification of plants carrying the mutant $A H A S$ allele was carried out using SSR marker RM6844 linked with AHAS gene at a distance of $1.2 \mathrm{cM}$ in chromosome 2 (Shoba et al. 2017), primer details are given in Table 1. For background selection, the primer sequence of genome-wide SSR markers was fetched from the rice marker database of Gramene (http://www.gramene.org). A total of 856 SSR markers were used to identify 112 polymorphic SSR markers between the parents PB 1121 and Robin, for use in background selection (Table 2). Agarose gel image and graphical presentation of all 112 polymorphic SSR markers is given in additional file 1: Figure S1 and additional file 2: Figure S2, respectively. Primers details are provided in additional file 5: Table S1. During the background selection in backcross generations, the homozygous and heterozygous plants for PB 1121 allele at each marker loci were counted separately. A reductionist strategy was considered for this, markers that were found to be homozygous for PB 1121 allele in a given generation were not included in subsequent generations for background selection. RPG recovery was estimated using the formula: 
$R P G$ recovery $(\%)=\frac{\text { Number of markers homozygous for } R P \text { alleles }+(0.5 * \text { Number of markers heterozygous })}{\text { Total number of polymoprhic markers used for background selection }} X 100$

The RPG recovery was visualized using Graphical GenoTypes (GGT) Version 2.0 software (Van Berloo 1999). Based on molecular marker analysis, similarity of NILs to PB 1121 was computed using Jaccard's coefficient of similarity for generating a dendrogram following an unweighted pair group method with arithmetic mean (UPGMA). Further, for cluster analysis, NTSYS-PC-2.02f (Rohlf 1998) was used.

\section{Molecular Screening for Aroma Gene}

The NILs and the parents were also screened for the presence of badh2 gene, responsible for aroma in Basmati rice, using gene based marker 'nksbad2' (Amarawathi et al. 2008). Primer details are given in Table 3.

\section{Screening for Imazethapyr Tolerance}

Twelve HT-NILs of PB 1121 along with PB 1121 and Robin were planted in a randomized complete block design (RCBD) with three replications and sprayed with herbicide, Imazethapyr (commercially available as Pursuit $^{\mathrm{Tm}}$ ) @ concentration of $2.5 \mathrm{ml} /$ liter, after 10 days of transplanting. Another set of same experimental material was grown side by side and used as unsprayed control with manual weeding. Visual observation of herbicide tolerance of the HT-NILs was made on 15 days after spray as per the standard protocol in rice (Shoba et al. 2017).

\section{Evaluation of Agro-Morphological, Grain and Cooking Quality Parameters}

Agro-morphological evaluation of the HT-NILs and parents was done in RCBD with three replications following recommended agronomic practices. Data on the agromorphological traits viz, days to 50\% flowering (DFF),

Table 2 Details of SSR markers used for parental polymorphic survey

\begin{tabular}{lllll}
\hline Markers used for & $\begin{array}{l}\text { Total } \\
\text { No. of } \\
\text { Markers } \\
\text { surveyed }\end{array}$ & $\begin{array}{l}\text { Total No. of } \\
\text { Polymorphic } \\
\text { markers }\end{array}$ & $\begin{array}{l}\text { Polymorphic } \\
\text { Markers used }\end{array}$ & $\begin{array}{l}\text { Polymorphism } \\
(\%)\end{array}$ \\
\hline Foreground & 1 & 1 & 1 & - \\
Background $^{\text {a }}$ & 856 & 112 & 112 & 13.08 \\
Chromosome 2 $^{2}$ & 96 & 18 & 18 & 18.75 \\
\hline
\end{tabular}

Includes markers on Chromosome 2 plant height $(\mathrm{PH})$, number of productive tillers per plant (NPT), panicle length (PL), spikelet fertility percent (SF $\%$ ), thousand grain weight (TGW) were recorded on five plants taken at random from the two middle rows of each plot under both sprayed and unsprayed conditions. The plot yield was recorded in kilogram/hectare $(\mathrm{kg} / \mathrm{ha})$ from each replication. The data on grain and cooking quality traits such as hulling percentage (HUL\%), milling percentage (MIL\%), head rice recovery percentage (HRR\%), kernel length before cooking (KLBC), kernel breadth before cooking (KBBC), kernel length after cooking (KLAC), kernel breadth after cooking (KBAC), kernel elongation ratio (ER), alkali spreading value (ASV) (Little 1958) and aroma (Sood and Siddiq 1978) was recorded.

The statistical analysis of agro-morphological data was carried out using CropStat 7.2 (IRRI, CropStat 7.2 2014). Student's $t$-test was performed for statistical significance differences for yield between unsprayed and herbicide sprayed condition at $P \leq 0.05$.

\section{Results}

Development of PB 1121-NILs with Herbicide Tolerance The recurrent parent PB 1121 and donor Robin were validated for their tolerance to herbicide, Imazethapyr. PB 1121 was highly susceptible and exhibited complete mortality within 15-20 days of herbicide spray, while the donor Robin was highly tolerant to Imazethapyr (Fig. 2). MABB was adopted to transfer the HT trait into PB 1121 from Robin. $F_{1}$ plants obtained from the cross, PB 1121 and Robin were confirmed for their hybridity using $A H A S$ gene linked SSR marker, RM6844 (Additional file 3: Figure S3). A true $F_{1}$ plant was backcrossed to $P B 1121$ and 262 $\mathrm{BC}_{1} \mathrm{~F}_{1}$ plants were generated. Of these, 128 plants were heterozygous for RM6844 with RPG recovery

Table 3 Details of nks_bad2 gene based SSR marker for aroma

\begin{tabular}{llllll}
\hline Marker & Primer Sequences & Tm & $\begin{array}{l}\text { PB1121 } \\
\text { Allele }\end{array}$ & $\begin{array}{l}\text { Robin } \\
\text { Allele }\end{array}$ & $\begin{array}{l}\text { Position } \\
\text { (Mb) }\end{array}$ \\
\hline nks_bad2 & F: GGTTGCATT & $58^{\circ} \mathrm{C}$ & $82 \mathrm{bp}$ & $90 \mathrm{bp}$ & Gene based \\
& ACTGGGAGTTATG & & & & \\
& R: TCCACAGAAA & & & & \\
& TTTGAAACAAA & & & & \\
\hline
\end{tabular}




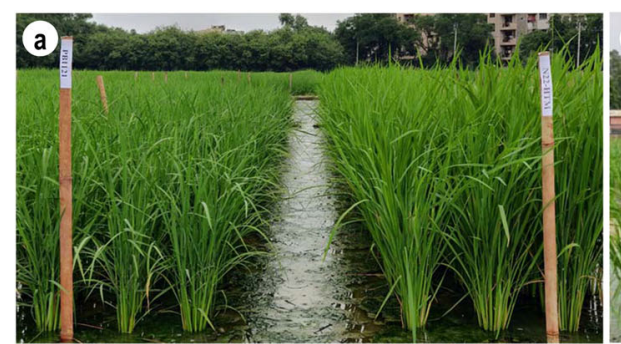

PB 1121

Robin

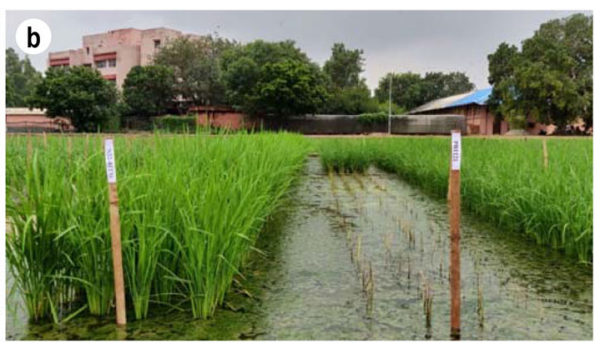

Robin

PB 1121

Fig. 2 Phenotypic evaluation of donor parent, "Robin" and recurrent parent, "PB 1121" for Imazethapyr herbicide tolerance @ concentration of 2.5 $\mathrm{ml} /$ liter, a Unsprayed, $\mathbf{b}$ Sprayed

ranging from $70.98-80.35 \%$. A plant, Pusa 1979-14 with the highest RPG (80.35\%) and with a higher level of phenotypic similarity to $\mathrm{PB} 1121$ was backcrossed and $188 \mathrm{BC}_{2} \mathrm{~F}_{1}$ plants were generated, of which 94 plants were heterozygous for foreground marker, RM6844 and the RPG recovery ranged from 81.25 to $92.85 \%$. The superior $\mathrm{BC}_{2} \mathrm{~F}_{1}$ plant was further backcrossed and $152 \quad \mathrm{BC}_{3} \mathrm{~F}_{1}$ seeds were produced, out of which 73 plants were found to be heterozygous for the foreground marker and these plants were subjected to phenotypic evaluation for agro-morphological traits and background selection was done using 16 SSR markers remained heterozygous in the $\mathrm{BC}_{2} \mathrm{~F}_{1}$ generation. The RPG recovery in the $\mathrm{BC}_{3} \mathrm{~F}_{1}$ generation ranged from 93.30 to $95.08 \%$. One superior $\mathrm{BC}_{3} \mathrm{~F}_{1}$ plant, with maximum RPG (95.08\%) and relatively superior recovery for RPP was backcrossed to generate $122 \mathrm{BC}_{4} \mathrm{~F}_{1}$ plants. A total of 58 plants were found to be heterozygous for RM6844 with RPG recovery range from 94.64 to 98.21\%. A plant with maximum RPG recovery (98.21\%) was selfed to produce $\mathrm{BC}_{4} \mathrm{~F}_{2}$ population.
Out of $384 \mathrm{BC}_{4} \mathrm{~F}_{2}$ plants, 88 plants were found to be homozygous for AHAS gene linked SSR marker RM6844 (Additional file 4: Figure S4).

The mutant $A H A S$ homozygous plants were evaluated for grain and cooking quality traits and 40 superior plants were identified. These 40 progenies were further evaluated for yield and quality traits. Based on the family bulk yield and quality traits, twelve families were selected for further detailed evaluation (Table 4). The RPG recovery of these families ranged from 98.66 to $99.55 \%$ with an average $99.10 \%$, some residual donor segments were observed in chromosome 8 and 11, whereas complete recovery was achieved in all other chromosomes (Fig. 3). All the PB 1121 HTNILs clustered together with PB 1121 with an average similarity index (SI) of 0.9756. Among the HT-NILs, Pusa 1979-14-7-33-99-15 and Pusa 1979-14-7-33-9966 showed maximum similarity with SI of 0.982 (Fig. 4).

Finally, selected $12 \quad \mathrm{BC}_{4} \mathrm{~F}_{4}$ families were validated for homozygosity for the mutated AHAS allele using gene linked SSR marker RM6844 (Fig. 5), and also

Table 4 Number of plants generated and recurrent parent genome recovery in the backcross generations during marker aided introgression of mutant AHAS allele in PB 1121

\begin{tabular}{|c|c|c|c|c|c|c|}
\hline Generation & $\begin{array}{l}\text { No. of plants } \\
\text { generated }\end{array}$ & $\begin{array}{l}\text { No. of plants carrying mutant } \\
\text { AHAS allele in heterozygous/ } \\
\text { homozygous state }\end{array}$ & $\begin{array}{l}\text { No. of selected } \\
\text { plants/families }\end{array}$ & $\begin{array}{l}\text { Genome } \\
\text { recovery (\%) }\end{array}$ & $\begin{array}{l}\text { Mean Observed RPG } \\
\text { Recovery (\%) }\end{array}$ & $\begin{array}{l}\text { Expected Average } \\
\text { Recovery (\%) }\end{array}$ \\
\hline$F_{1}$ & 15 & $15^{\mathrm{b}}$ & 1 & a & & \\
\hline $\mathrm{BC}_{1} \mathrm{~F}_{1}$ & 262 & $128^{\mathrm{b}}$ & 1 & $70.98-80.35$ & 75.66 & 75 \\
\hline $\mathrm{BC}_{2} \mathrm{~F}_{1}$ & 188 & $94^{b}$ & 1 & $81.25-92.85$ & 87.05 & 87.5 \\
\hline $\mathrm{BC}_{3} \mathrm{~F}_{1}$ & 152 & $73^{b}$ & 1 & $93.30-95.08$ & 94.19 & 93.8 \\
\hline $\mathrm{BC}_{4} \mathrm{~F}_{1}$ & 122 & $58^{b}$ & 1 & $94.64-98.21$ & 96.42 & 96.9 \\
\hline $\mathrm{BC}_{4} \mathrm{~F}_{2}$ & 384 & $88^{c}$ & 40 & a & - & - \\
\hline $\mathrm{BC}_{4} \mathrm{~F}_{3}$ & 40 & $40^{c}$ & 12 & a & - & - \\
\hline $\mathrm{BC}_{4} \mathrm{~F}_{4}$ & 12 & $12^{c}$ & 12 & $98.66-99.55$ & 99.10 & - \\
\hline
\end{tabular}

${ }^{\text {a Not estimated }}$

bPlants with mutant AHAS allele in heterozygous state

'Plants homozygous for mutant AHAS allele 


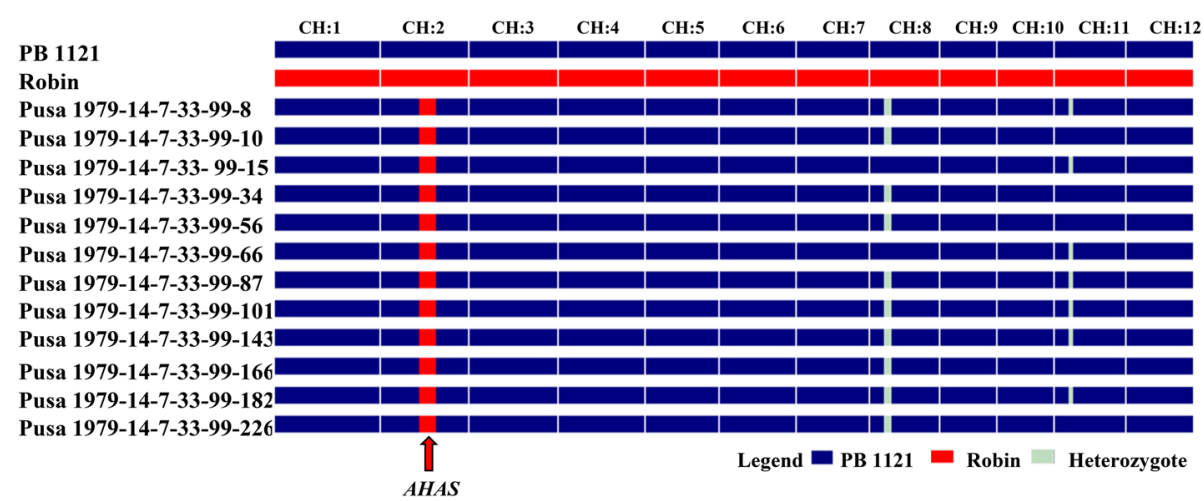

Fig. 3 Graphical representation of PB 1121 HT-NILS carrying mutant AHAS gene showing the extent of recurrent parent genome (RPG) recovery. $\mathrm{CH}$ : chromosome

evaluated for Imazethapyr tolerance, agronomic, grain and cooking quality characters in the sprayed and unsprayed condition in a replicated trial.

\section{Evaluation of PB 1121- HT NILs for Tolerance to Herbicide Imazethapyr}

The PB 1121 HT-NILs along with parents, PB 1121 and Robin were screened for tolerance to herbicide Imazethapyr. All the NILs homozygous for the mutant AHAS allele exhibited complete tolerance to Imazethapyr. The level of herbicide tolerance in NILs was comparable to DP Robin. While, the RP PB 1121 possessing the wild type $A H A S$ allele did not survive after herbicide spray and showed complete mortality within 15 to 20 days of the Imazethapyr spray (Fig. 6).

\section{Evaluation of PB 1121 HT-NILs for Agronomic, Grain and Cooking Quality}

The mean performance of PB 1121 HT-NILs for yield, yield components and phenological traits, when grown under herbicide sprayed and unsprayed conditions were recorded. All the data from the sprayed condition and only yield data for unsprayed conditions are presented in Table 5. Under herbicide sprayed conditions, PB 1121 showed complete mortality within 15-20 days of spray, while the NILs showed

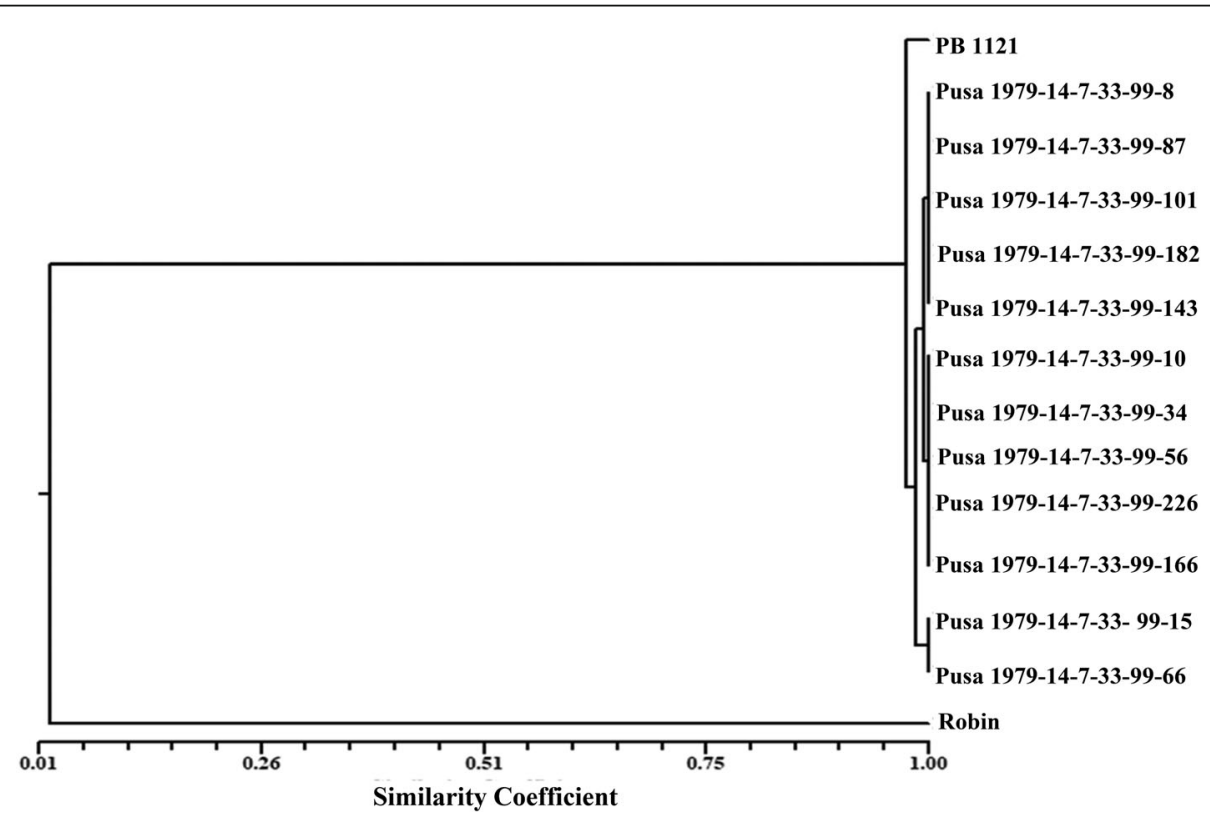

Fig. 4 Dendrogram showing the genetic relationship among different PB $1121 \mathrm{HT}-\mathrm{NILS}$ in $\mathrm{BC}_{4} \mathrm{~F}_{4}$ generation and their parents, PB 1121 and Robin based on 112 polymorphic SSR markers 


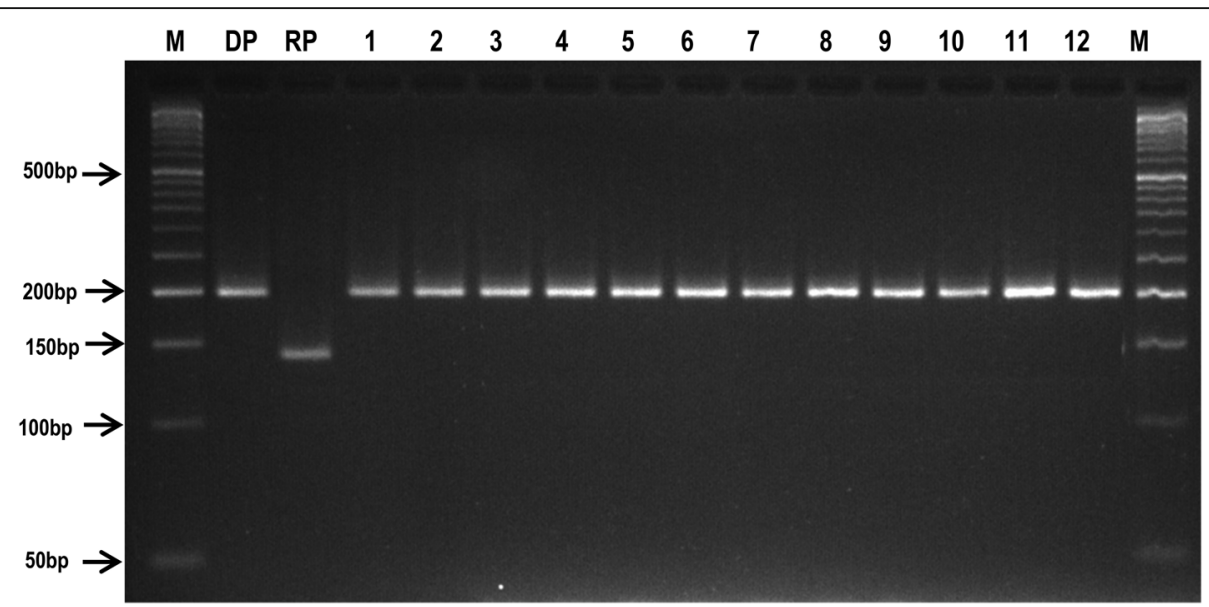

Fig. 5 A representative gel image showing the amplification profile of AHAS gene linked marker RM6844 in the PB 1121 HT-NILs along with recurrent parent (RP), PB 1121 and donor parent (DP) Robin. M: 50 base pair DNA ladder, DP: Robin, RP: PB 1121, 1-12: PB 1121 HT-NILs, Pusa 1979-14-7-33-99-8, Pusa 1979-14-7-33-99-10, Pusa 1979-14-7-33- 99-15, Pusa 1979-14-7-33-99-34, Pusa 1979-14-7-33-99-56, Pusa 1979-14-7-33-9966, Pusa 1979-14-7-33-99-87, Pusa 1979-14-7-33-99-101, Pusa 1979-14-7-33-99-143, Pusa 1979-14-7-33-99-166, Pusa 1979-14-7-33-99-182 and Pusa 1979-14-7-33-99-226

normal growth and development (Fig. 7). Therefore, the yield and quality traits of NILs under sprayed condition were compared with the data of PB 1121 from unsprayed conditions. It was observed that NILs were at par with PB 1121 in yield, grain and cooking quality traits. NILs Pusa 1979-14-7-33-99-66 and Pusa 1979-14-7-33-99-143 were slightly taller in stature and the NILs Pusa 1979-14-7-33-99-15, Pusa 197914-7-33-99-10 and Pusa 1979-14-7-33-99-66 were significantly superior in yield as compared to PB 1121 (Fig. 8 \& Table 5) which could be attributed to its higher spikelet fertility. There was no significant difference in the performance of NILs when compared under sprayed and unsprayed conditions (based on Student t-test) while PB 1121 was completely dead under sprayed condition.

The mean performance of grain and cooking quality traits of the PB 1121 HT-NILs evaluated under sprayed condition is presented in Table 6. All the NILs possessed extra-long slender grain type with a very strong aroma, and ASV of 7.0, which was similar to that of PB 1121. HUL\%l, MIL\%, HRR\%, KLBC, $\mathrm{KBBC}$, and KBAC were comparable to PB 1121. Three NILs namely, Pusa 1979-14-7-33-99-15, Pusa 1979-14-7-33-99-10 and Pusa 1979-14-7-33-99-143 were found significantly superior for KLAC and elongation ratio as compared to PB 1121 (Table 6 \& Fig. 9).

Based on molecular analysis of badh2 locus, all the HT-NILs were confirmed to have badh2 allele with $8 \mathrm{bp}$ deletion which is identical to $\mathrm{PB} 1121$ (Fig. 10). In sensory evaluation, the HT-NILs were found to be strongly scented with an aroma score of 3 .

\section{Discussion}

Basmati rice of India attracts consumers worldwide due to its peerless grain and cooking quality characteristics and appealing aroma. Among the Basmati rice varieties developed in India, PB 1121 is considered as the hallmark of Basmati, owing to its exceptional KLAC (20 to $25 \mathrm{~mm}$ ) and high volume expansion upon cooking ( $>4$ times) (Singh et al. 2018b). Basmati rice is protected under Geographical Indications (GI) for cultivation in seven states of north-western India where rice is primarily cultivated under transplanted conditions. However, due to the limited availability of labor on time, high transplanting cost and depleting water table, there is a need to shift rice cultivation to DSR. Although DSR is a potential technology, the response of farmers for its adoption has been lukewarm owing to heavy weed infestation under DSR. Herbicide tolerant rice varieties provide a potential alternative for effective weed management under DSR.

MABB has several advantages over conventional breeding and has been successfully deployed for improving elite rice varieties for resistance to biotic stresses such as bacterial blight and blast (Joseph et al. 2004; Gopalakrishnan et al. 2008; Singh et al. 2012a, 2012b; Singh et al. 2013; Khanna et al. 2015; Ellur et al. 2016a, 2016b), and abiotic stresses such as salinity tolerance (Babu et al. 2017; Singh et al. 2018a) which it has 

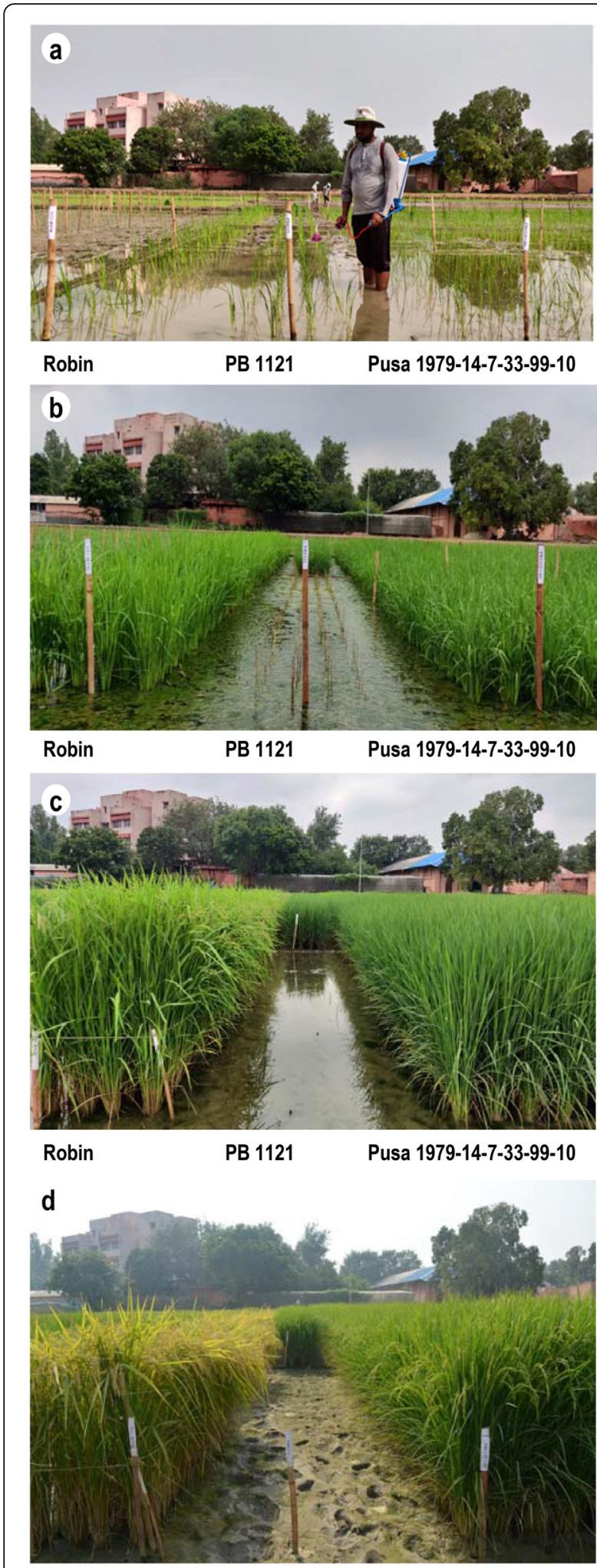

Robin

PB 1121
Fig. 6 Phenotypic screening of PB 1121-HT NILs along with Recurrent Parent (RP), PB 1121 and Donor Parent, Robin for tolerance to the herbicide, Imazethapyr, a application of Imazethapyr @ $2.5 \mathrm{ml} /$ liter after 10 days of transplanting, b 20 days after herbicide spray showing that complete death of RP, c 60 days after herbicide spray, $\mathbf{d} 90$ days after herbicide spray

brought a paradigm shift in Basmati rice breeding (Singh et al. 2011).

In this study, we report the transfer of herbicide tolerance trait from Robin into the genetic background of PB 1121 through MABB. Robin is an EMS induced mutant of an upland drought tolerant rice variety N22, which possess tall plant stature, short grains and lacks aroma (Shoba et al. 2017). Using poor grain quality DP to transfer HT trait into the genetic background of high quality Basmati rice variety $\mathrm{PB} 1121$, is a challenging task especially for the recovery of exquisite grain and cooking quality of this Basmati rice variety in the improved HT-NILs. Foreground selection together with background and phenotypic selection led to precise transfer of mutant AHAS allele for herbicide tolerance as well as accelerated the RPG recovery to an extent of 98.66 to $99.55 \%$ with four backcross generations. The complete recovery of RPG in mutant AHAS gene carrier chromosome as well as rest of chromosome was achieved except chromosomes 8 and 11, which retained some residual donor fragment (Fig. 3). Using the SSR markers for background analysis generally target the non-coding and heterochromatic regions and hence could not quantify the recovery of functional part of the genome. Therefore, background selection was coupled with phenotypic selection for RPP which helped in speeding the process of reconstruction of RPP as it entails the indirect selection for functionally expressed part of the genome (Ellur et al. 2016a).

PB 1121 HT-NILs were at par with PB 1121 for agro-morphological, grain and cooking quality traits, while exhibiting herbicide tolerance similar to Robin. This was possible due to stringent phenotypic selection for agro-morphological traits, grain and cooking quality traits for RP PB 1121 phenotype carried out in each of the backcross generations. The significance of phenotypic selection with background selection in the development of NILs with maximum RPG and RPP recovery has also been earlier demonstrated (Ellur et al. 2016b; Babu et al. 2017). Three NILs, Pusa 1979-14-7-33-99-15, Pusa 1979-14-7-33-99-10 and Pusa 1979-14-7-33-99-66 were significantly superior in yield, grain and cooking quality as compared to PB 1121 indicating the effectiveness of augmenting 
Table 5 Agronomic performance of PB 1121 HT-NILs in comparison with the recurrent parent PB 1121

\begin{tabular}{|c|c|c|c|c|c|c|c|c|c|}
\hline \multirow[t]{2}{*}{ Genotype } & \multirow[t]{2}{*}{ DFF } & \multirow[t]{2}{*}{$\mathrm{PH}$} & \multirow[t]{2}{*}{ NPT } & \multirow[t]{2}{*}{$P L$} & \multirow[t]{2}{*}{$\mathrm{SF} \%$} & \multirow[t]{2}{*}{ TGW } & \multicolumn{2}{|l|}{ YLD (kg/ha) } & \multirow[t]{2}{*}{$\% R P C$} \\
\hline & & & & & & & USP & $\mathrm{SP}$ & \\
\hline Pusa 1979-14-7-33-99-8 & 106.0 & 123.15 & 19.30 & 27.89 & 88.20 & 28.87 & $6701 \pm 274.40$ & $6517 \pm 311.34$ & 98.66 \\
\hline Pusa 1979-14-7-33-99-10 & $109.0^{*}$ & 122.45 & $20.60^{*}$ & 28.40 & $92.70^{*}$ & 28.73 & $7129 \pm 322.95^{*}$ & $7217 \pm 425.32^{*}$ & 99.11 \\
\hline Pusa 1979-14-7-33- 99-15 & 106.0 & 131.53 & $20.20^{*}$ & 28.52 & $92.87^{*}$ & 28.93 & $7310 \pm 382.05^{*}$ & $7417 \pm 467.53^{*}$ & 99.55 \\
\hline Pusa 1979-14-7-33-99-34 & 107.0 & 126.25 & $19.70^{*}$ & 29.28 & 87.53 & 27.99 & $6673 \pm 497.09$ & $6255 \pm 350.39$ & 99.11 \\
\hline Pusa 1979-14-7-33-99-56 & 106.5 & 128.85 & 17.20 & 27.56 & 87.75 & 28.88 & $6836 \pm 359.89$ & $6582 \pm 300.78$ & 99.11 \\
\hline Pusa 1979-14-7-33-99-66 & 106.5 & $136.85^{*}$ & $19.10^{*}$ & 29.29 & $92.74^{*}$ & 28.32 & $7248 \pm 237.14^{*}$ & $7300 \pm 490.75^{*}$ & 99.55 \\
\hline Pusa 1979-14-7-33-99-87 & 105.5 & 127.95 & 15.70 & 28.79 & 71.48 & 26.43 & $4716 \pm 379.94$ & $4634 \pm 358.83$ & 98.66 \\
\hline Pusa 1979-14-7-33-99-101 & 105.5 & 125.10 & 13.80 & 27.58 & 86.64 & 27.32 & $5799 \pm 368.33$ & $5866 \pm 231.13$ & 98.66 \\
\hline Pusa 1979-14-7-33-99-143 & 106.0 & $134.35^{*}$ & 15.50 & 28.56 & 84.80 & 28.30 & $5832 \pm 586.79$ & $5559 \pm 265.96$ & 98.66 \\
\hline Pusa 1979-14-7-33-99-166 & 107.0 & 133.47 & 17.30 & 27.73 & 89.11 & 28.54 & $6910 \pm 426.37$ & $7017 \pm 522.41$ & 99.11 \\
\hline Pusa 1979-14-7-33-99-182 & 107.5 & 124.85 & 16.90 & 27.33 & 87.11 & 27.92 & $6502 \pm 346.16$ & $6506 \pm 316.17$ & 98.66 \\
\hline Pusa 1979-14-7-33-99-226 & 106.0 & 126.00 & 16.80 & 27.48 & 88.14 & 27.90 & $6599 \pm 368.68$ & $6547 \pm 282.89$ & 99.11 \\
\hline PB $1121^{a}$ & 106.0 & 125.58 & 16.06 & 29.81 & 86.10 & 28.92 & $6250 \pm 369.38$ & - & - \\
\hline CD (0.05) & 2.90 & 7.39 & 2.76 & 1.31 & 5.35 & 1.29 & 868.26 & 828.96 & - \\
\hline
\end{tabular}

Data on DFF, PH, NPT, PL, SF\%, TGW presented is from Imazethapyr sprayed plots while the yield data (YLD) is presented for both unsprayed and herbicide sprayed plots. *Significant at 5\%; DFF days to 50\% flowering, PH Plant height in $\mathrm{cm}$, NPT Number of productive tillers, PL Panicle length in $\mathrm{cm}$, SF Spikelet fertility percentage, TGW Thousand grain weight in grams (g), YLD Plot yield in kg/ha, USP Unsprayed condition, SP herbicide (Imazethapyr) Sprayed condition, RPG Recurrent Parent Genome, CD Critical difference. "Data on DFF, PH, NPT, PL, SF\%, TGW for PB 1121 is from unsprayed plots for comparison, as PB 1121 did not survive under Imazethapyr spray
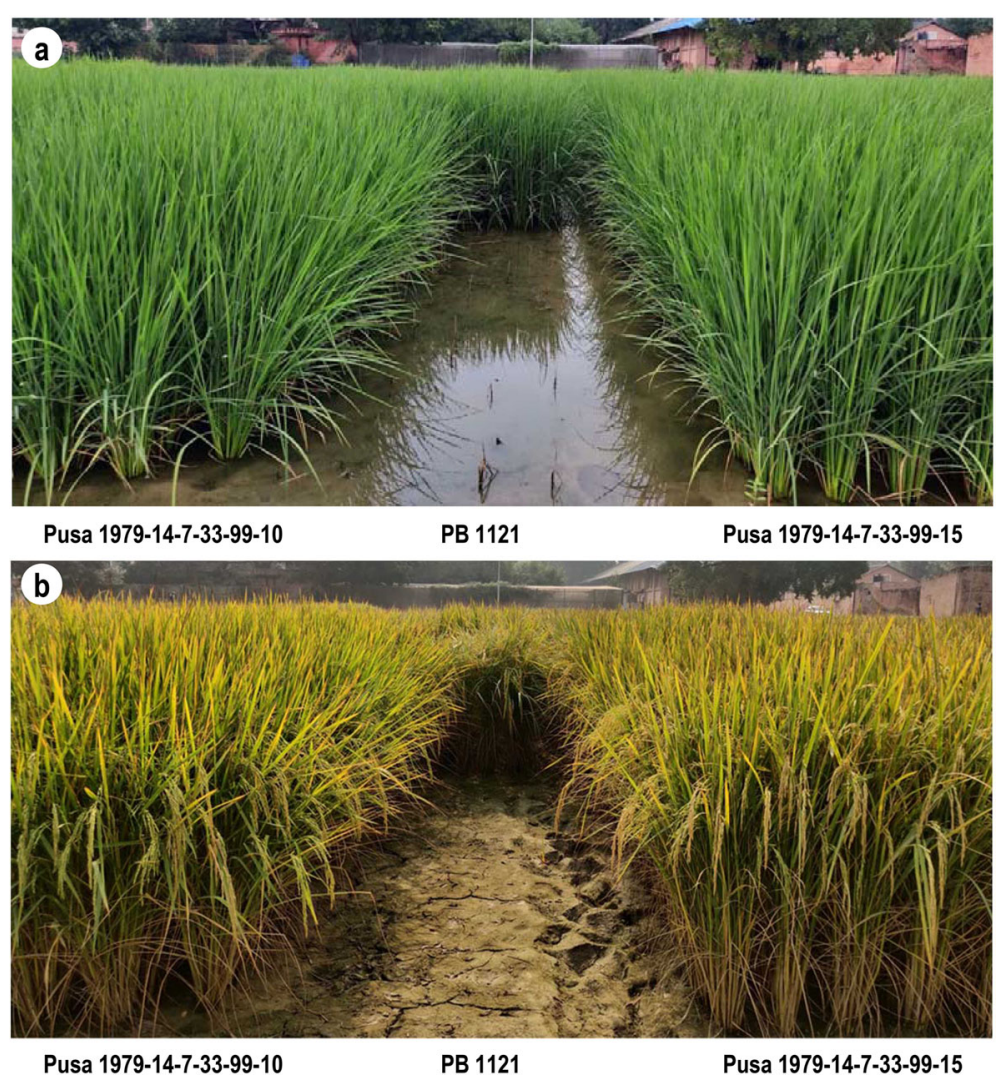

Fig. 7 Field view of the PB 1121 HT-NILs at (a) booting and (b) maturity 


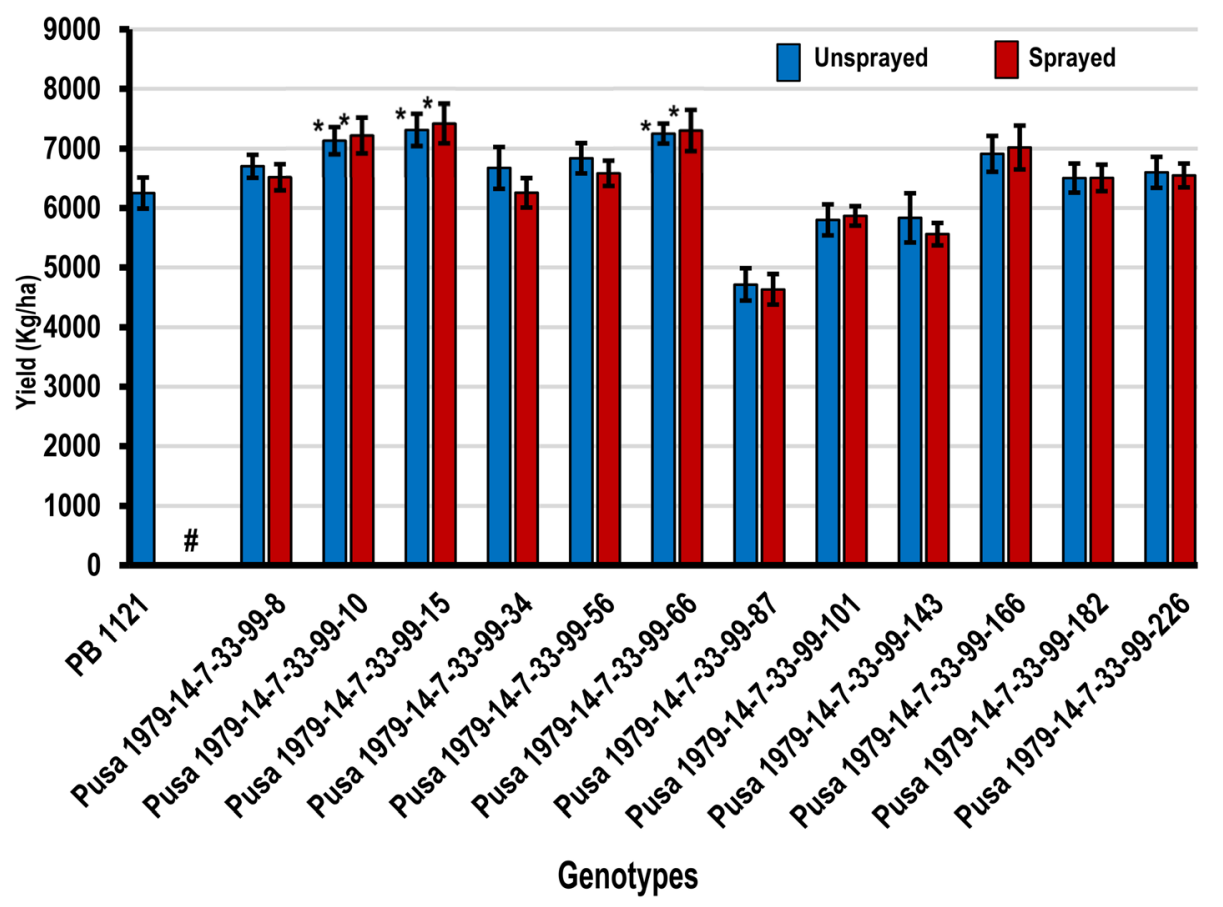

Fig. 8 Comparison of yield (kg/ha) between PB 1121 HT-NILs and their parents in unsprayed and herbicide sprayed condition; \#PB 1121 seedling did not survive Imazethapyr spray; *Significantly superior to the recurrent parent, PB 1121

Table 6 Grain quality traits of PB 1121 HT-NILs in comparison to PB 1121

\begin{tabular}{lllllllllll}
\hline Genotype & HUL & MIL & HRR & KLBC & KBBC & KLAC & KBAC & E/R & ASV & AROMA \\
\hline Pusa 1979-14-7-33-99-8 & 77.77 & 67.46 & 55.96 & 8.77 & 1.61 & 18.54 & 2.28 & 2.11 & 7 & 3 \\
Pusa 1979-14-7-33-99-10 & 79.77 & 70.40 & 58.40 & 8.56 & 1.69 & $19.66^{*}$ & 2.36 & $2.29^{*}$ & 7 & 3 \\
Pusa 1979-14-7-33- 99-15 & 78.92 & 68.33 & 54.83 & 8.71 & 1.68 & $19.69^{*}$ & 2.29 & $2.26^{*}$ & 7 & 3 \\
Pusa 1979-14-7-33-99-34 & 76.70 & 66.73 & 55.13 & 8.83 & 1.67 & 19.35 & 2.32 & 2.18 & 7 & 3 \\
Pusa1979-14-7-33-99-56 & 78.66 & 67.90 & 53.80 & 8.81 & 1.64 & 19.10 & 2.31 & 2.16 & 7 & 3 \\
Pusa 1979-14-7-33-99-66 & 78.23 & 68.33 & 56.05 & 8.72 & 1.63 & 18.97 & $2.48^{*}$ & 2.18 & 7 & 3 \\
Pusa 1979-14-7-33-99-87 & 77.50 & 69.23 & 55.36 & 8.62 & 1.69 & 18.46 & 2.31 & 2.14 & 7 & 3 \\
Pusa 1979-14-7-33-99-101 & 81.12 & 70.25 & 57.15 & 8.82 & 1.67 & 19.32 & 2.33 & 2.19 & 7 & 3 \\
Pusa 1979-14-7-33-99-143 & 78.60 & 69.65 & 56.67 & 8.97 & 1.74 & $20.29^{*}$ & 2.32 & $2.26^{*}$ & 7 & 3 \\
Pusa 1979-14-7-33-99-166 & 77.07 & 67.89 & 54.09 & 8.75 & 1.67 & 18.88 & 2.31 & 2.16 & 7 & 3 \\
Pusa 1979-14-7-33-99-182 & 77.76 & 66.64 & 54.95 & 8.73 & 1.64 & 19.32 & 2.31 & 2.21 & 7 \\
Pusa 1979-14-7-33-99-226 & 77.45 & 67.63 & 55.42 & 8.68 & 1.69 & 19.04 & 2.35 & 2.19 & 7 \\
PB 1121 & 78.15 & 69.70 & 55.80 & 8.76 & 1.68 & 18.82 & 2.30 & 2.15 & 7 \\
CD (0.05) & $\mathbf{3 . 4 1}$ & $\mathbf{3 . 9 9}$ & $\mathbf{3 . 2 7}$ & $\mathbf{0 . 3 1}$ & $\mathbf{0 . 0 9}$ & $\mathbf{0 . 7 8}$ & $\mathbf{0 . 0 8}$ & $\mathbf{0 . 0 8}$ & -3 & 3 \\
\hline
\end{tabular}

${ }^{*}$ Significant at 5\%; HUL hulling recovery in percentage, MIL milling recovery in percentage, $H R R$ head rice recovery in percentage, $K L B C$ kernel length before cooking in $\mathrm{mm}, K B B C$ kernel breadth before cooking in $\mathrm{mm}, K L A C$ kernel length after cooking in mm, KBAC kernel breadth after cooking in mm, $E / R$ kernel

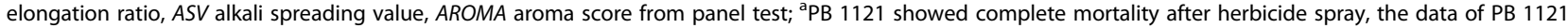
taken from the unsprayed area is presented for the purpose of comparison 


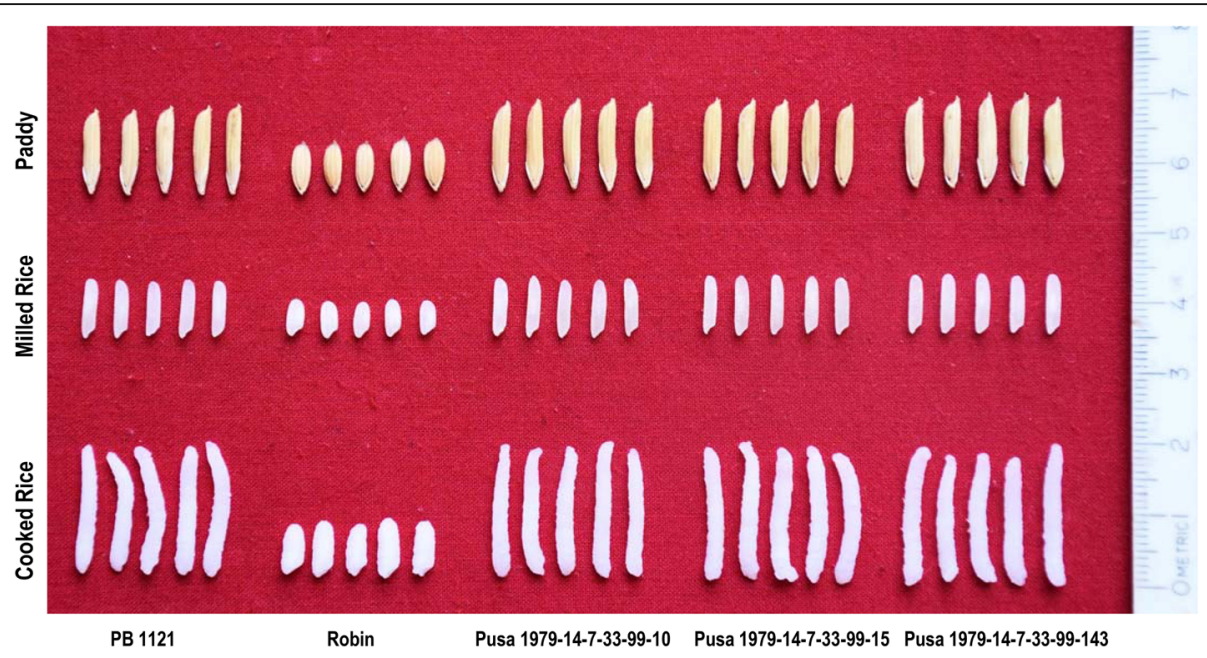

Fig. 9 Grain and cooking quality of selected PB 1121 HT-NILs and their parents, PB 1121 and Robin

rigorous phenotypic selection for the cooking quality traits along with background selection.

Pleasant aroma is an essential trait of Basmati rice, which is primarily governed by a recessive gene badh 2 located on chromosome 8 . The accumulation of 2acetyl-1-pyrroline (2-AP) in aromatic rice is explained by the loss of function mutations in the badh2 gene (Bradbury et al. 2005; Chen et al. 2008). All the PB 1121 HT-NILs and the recurrent parent PB 1121 were found to carry an 8 bp deletion corresponding to the aromatic allele for the production of 2-AP (Fig. 10).

AHAS is an enzyme which catalyzes two reactions for the synthesis of branched chain amino acids namely, valine, leucine, and isoleucine (Singh and Shaner 1995). Condensation of two pyruvate molecules forms 2acetolactate which leads to the formation of valine and leucine. While for isoleucine biosynthesis, 2acetohydroxybutyrate is synthesized from pyruvate and 2-ketobutyrate (Zhou et al. 2007). AHAS-inhibiting herbicides block the substrate access channel in the AHAS enzyme by binding to it and elicit deficiency of branched-chain amino acids (Garcia et al. 2017). The resulting decrease of protein synthesis slows down cell division thus leading to growth difficulties in plants $(\mathrm{Yu}$ and Powles 2014). However, the mutations within the AHAS gene results in altered AHAS enzyme which confers resistance to the AHAS inhibiting herbicides (Tranel and Wright 2002; Duggleby and Pang 2000; Christoffers et al. 2006). All the PB 1121 HT-NILs carrying mutated AHAS allele displayed tolerance to Imazethapyr herbicide when applied @ $2.5 \mathrm{ml} /$ liter with no significant difference in the yield performance, grain and cooking

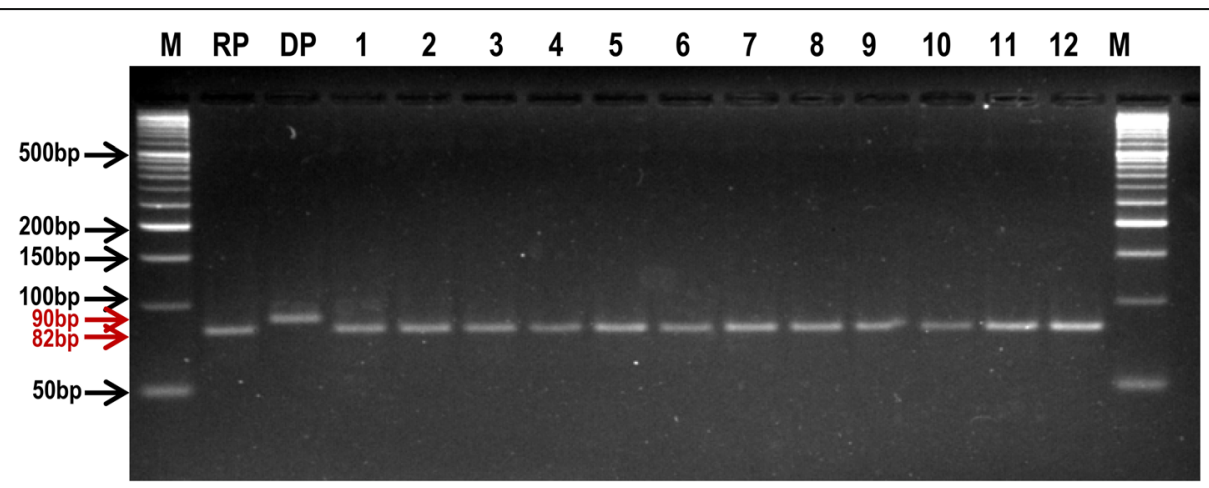

Fig. 10 A representative image showing the amplification profile of the marker, "nksbad2" based on 8 bp deletion in badh2 in the PB 1121 HTNILs along with recurrent parent (RP), PB 1121 and the non-aromatic donor parent (DP) Robin. M: 50 base pair DNA ladder, RP: PB 1121, DP: Robin, 1-12: PB 1121 HT-NILs, Pusa 1979-14-7-33-99-8, Pusa 1979-14-7-33-99-10, Pusa 1979-14-7-33- 99-15, Pusa 1979-14-7-33-99-34, Pusa 1979-147-33-99-56, Pusa 1979-14-7-33-99-66, Pusa 1979-14-7-33-99-87, Pusa 1979-14-7-33-99-101, Pusa 1979-14-7-33-99-143, Pusa 1979-14-7-33-99-166, Pusa 1979-14-7-33-99-182 and Pusa 1979-14-7-33-99-226 
quality traits when compared to HT-NILs under unsprayed conditions. This indicates the effectiveness of mutant AHAS gene to overcome the adverse effect of herbicide Imazethapyr.

In all, the present study reports successful development of HT NILs in the genetic background of popular Basmati rice variety PB 1121 by introgression of mutated AHAS allele using MABB program. The PB $1121 \mathrm{HT}$ NILs are being evaluated in the National Basmati Trials for their subsequent release as commercial varieties. These NILs will help the farmers in adopting DSR in Basmati rice production which would help in economizing the rice production.

\section{Supplementary information}

Supplementary information accompanies this paper at https://doi.org/10. 1186/s12284-020-00423-2.

Additional file 1: Figure S1. Agarose gel image (a-e) of all 112 SSR markers polymorphic between RP PB 1121 and DP Robin. M: 50 base pair DNA ladder; P1: PB 1121; P2: Robin.

Additional file 2: Figure S2. Chromosome wise Graphical representation of all 112 SSR markers polymorphic between RP PB 1121 and DP Robin.

Additional file 3: Figure S3. Gel image showing the amplification profile of AHAS linked SSR marker RM6844 in the $\mathrm{F}_{1}$ plants. M: 50 base pair DNA ladder; DP: Robin; RP: PB 1121; 1-15: F 1 plants.

Additional file 4: Figure S4. A representative gel amplification image of the SSR marker, RM6844 used in foreground selection in the $\mathrm{BC}_{4} \mathrm{~F}_{2}$ population. M: 50 base pair DNA ladder; RP: PB 1121; DP: Robin; 1-68: $\mathrm{BC}_{4} \mathrm{~F}_{2}$ plants.

Additional file 5: Table S1. Details of 112 polymorphic SSR markers used in Background selection for development of PB 1121 HT-NILs.

\section{Abbreviations}

DSR: Direct-seeded rice; HT: Herbicide tolerant; MABB: Marker assisted backcross breeding; AHAS: Acetohydroxy acid synthase; PB: Pusa Basmati; DP: Donor parent; RP: Recurrent parent; NIL: Near-isogenic line; RPP: Recurrent parent phenome; RPG: Recurrent parent genome; SSR: Simple sequence repeat; ALS: Acetolactate synthase; EMS: Ethyl methane sulfonate; 2-AP: 2-acetyl-1-pyrroline; CD: Critical difference

\section{Acknowledgments}

The senior author acknowledges the help rendered by the technical and supporting staff of the rice Genetics, Division of Genetics, for field work.

\section{Authors' Contributions}

The study is part of the Ph.D. thesis research of the first author. N.G. performed the experiments and prepared the manuscript; N.G., A.K.Y. conducted herbicide phenotypic screening; A.K.Y., R.K.E. did the statistical analysis; G.K.S., P.K.B., H. B, K.K.V., C.V., A.M.V.S. and N.M. guided field experiments; A.K., R.K.E. reviewed the manuscript; N.K.S., T.M., supervised the project; A.K.S:, G.K.S. conceptualized and supervised the project, edited and finalized the manuscript. All the authors have read and approved the final manuscript.

\section{Funding}

The research work supported grants by the Department of Biotechnology, Ministry of Science and Technology, Government of India, through the network project on "Maintenance, Characterization and use of EMS mutants of Upland Variety Nagina 22 for Functional Genomics in Rice-Phase-II" (BT/PR 10787/AGIII/103/883/2014).

\section{Availability of Data and Materials}

All relevant data are provided as Tables within the paper and in the Supporting Information files.

\section{Ethics Approval and Consent to Participate}

Not applicable.

\section{Consent for Publication}

Not applicable.

\section{Competing Interests}

The authors declare that they have no competing interests.

\section{Author details}

${ }^{1}$ Division of Genetics, ICAR-Indian Agricultural Research Institute, New Delh 110012, India. ${ }^{2}$ Amity Institute of Biotechnology, Amity University, Noida, Uttar Pradesh 201303, India. ${ }^{3}$ Rice Breeding and Genetics Research Centre, ICAR-Indian Agricultural Research Institute, Aduthurai, Tamil Nadu 612101, India. ${ }^{4}$ Division of Plant Physiology, ICAR-Indian Agricultural Research Institute, New Delhi 110012, India. ${ }^{5}$ ICAR-National Institute for Plant Biotechnology, New Delhi 110012, India. ${ }^{6}$ Indian Council of Agricultural Research, Krishi Bhawan, New Delhi 110001, India.

Received: 28 May 2020 Accepted: 20 August 2020

Published online: 15 September 2020

\section{References}

Amarawathi $Y$, Singh R, Singh AK, Singh VP, Mohapatra T, Sharma TR, Singh NK (2008) Mapping of quantitative trait loci for basmati quality traits in rice (Oryza sativa L.). Mol Breed 21(1):49-65

Anderson PC, Georgeson M (1989) Herbicide-tolerant mutants of corn. Genome 31(2):994-999

Babu NN, Krishnan SG, Vinod KK, Krishnamurthy SL, Singh VK, Singh MP, Singh R, Ellur RK, Rai V, Bollinedi H, Bhowmick PK (2017) Marker aided incorporation of Saltol, a major QTL associated with seedling stage salt tolerance, into Oryza sativa 'Pusa basmati 1121'. Front in plant sci 8:41

Bradbury LM, Fitzgerald TL, Henry RJ, Jin Q, Waters DL (2005) The gene for fragrance in rice. Plant biotech journal 3(3):363-370

Chen S, Yang Y, Shi W, Ji Q, He F, Zhang Z, Cheng Z, Liu, Xu M (2008) The Plant Cell 20(7):1850-1861.

Christoffers MJ, Nandula VK, Howatt KA, Wehking TR (2006) Target-site resistance to acetolactate synthase inhibitors in wild mustard (Sinapis arvensis). Weed Sci 54(2):191-197

Doyle J (1991) DNA protocols for plants. In: Hewitt GM, Johnston AWB, Young JPW (eds) Molecular techniques in taxonomy. NATO ASI series (series $\mathrm{H}$ : cell biology), vol. 57. Springer, Berlin, Heidelberg

Duggleby RG, Pang SS (2000) Acetohydroxyacid synthase. BMB Rep 33(1):1-36

Ellur RK, Khanna A, Gopala Krishnan S, Bhowmick PK, Vinod KK, Nagarajan M, Mondal KK, Singh NK, Singh K, Prabhu KV, Singh AK (2016a) Marker-aided incorporation of Xa38, a novel bacterial blight resistance gene, in PB 1121 and comparison of its resistance Spectrum with xa13+Xa21. Sci Rep 6(1):1-8

Ellur RK, Khanna A, Yadav A, Pathania S, Rajashekara H, Singh VK, Gopala Krishnan S, Bhowmick PK, Nagarajan M, Vinod KK, Prakash G, Mondal KK, Singh NK, Prabhu KV, Singh AK (2016b) Improvement of basmati rice varieties for resistance to blast and bacterial blight diseases using marker assisted backcross breeding. Plant Sci 242:330-341

Garcia MD, Nouwens A, Lonhienne TG, Guddat LW (2017) Comprehensive understanding of acetohydroxyacid synthase inhibition by different herbicide families. Proc of the Nat Aca of Sci 114(7):E1091-E1100

Gopalakrishnan S, Sharma RK, Anand Rajkumar K, Joseph M, Singh VP, Singh AK, Bhat KV, Singh NK, Mohapatra T (2008) Integrating marker assisted background analysis with foreground selection for identification of superior bacterial blight resistant recombinants in basmati rice. Plant Breed 127(2):131-139

IRRI, CropStat 7.2 (2014) Biometrics and breeding informatics, PBGB Division, International Rice Research Institute, Los Baños

Joseph M, Gopalakrishnan S, Sharma RK, Singh VP, Singh AK, Singh NK Mohapatra T (2004) Combining bacterial blight resistance and basmati quality characteristics by phenotypic and molecular marker-assisted selection in rice. Mol Breed 13(4):377-387

Khanna A, Sharma V, Ellur RK, Shikari AB, Krishnan SG, Singh UD, Prakash G, Sharma TR, Rathour R, Variar M, Prashanthi SK (2015) Development and 
evaluation of near-isogenic lines for major blast resistance gene (s) in basmati rice. Theoretical and App Gen 128(7):1243-1259

Little RR (1958) Differential effect of dilute alkali on 25 varieties of milled white rice. Cereal Chem 35:111-126

Pathak H, Tewari AN, Sankhyan S, Dubey DS, Mina U, Singh VK, Jain N (2011) Direct-seeded rice: potential, performance and problems-Areview. Current Adv in Agri Sci 3(2):77-88

Piao Z, Wang W, Wei Y, Zonta F, Wan C, Bai J, Wu S, Wang X, Fang J (2018) Characterization of an acetohydroxy acid synthase mutant conferring tolerance to imidazolinone herbicides in rice (Oryza sativa). Planta 247(3): 693-703

Powles SB, Yu Q (2010) Evolution in action: plants resistant to herbicides. Annu Rev Plant Biol 61:317-347

Rao AN, Wani SP, Ramesha M, Ladha JK (2015) Weeds and weed management of rice in Karnataka state, India. Weed Technol 29(1):1-7

Rohlf FJ (1998) Numerical taxonomy and multivariate analysis system (NTSYSpc): Ver. 2.0. Exeter publication, Setauket, NY

Shoba D, Raveendran M, Manonmani S, Utharasu S, Dhivyapriya D, Subhasini G, Ramchandar S, Valarmathi R, Grover N, Krishnan SG, Singh AK (2017) Development and genetic characterization of a novel herbicide (Imazethapyr) tolerant mutant in rice (Oryza sativa L.). Rice 10(1):1-12

Singh A, Singh VK, Singh SP, Pandian RT, Ellur RK, Singh D, Bhowmick PK, Gopala Krishnan S, Nagarajan M, Vinod KK, Singh UD (2012a) Molecular breeding for the development of multiple disease resistance in basmati rice. AoB Plants 2012:pls029

Singh AK, Gopalakrishnan S, Singh VP, Prabhu KV, Mohapatra T, Singh NK, Sharma TR, Nagarajan M, Vinod KK, Singh D, Singh UD (2011) Marker assisted selection: a paradigm shift in basmati breeding. Indian J Genet 71(2):120

Singh BK, Shaner DL (1995) Biosynthesis of branched chain amino acids: from test tube to field. Plant Cell 7(7):935

Singh V, Singh AK, Mohapatra T, Gopala KS, Ellur RK (2018b) Pusa Basmati 1121-a rice variety with exceptional kernel elongation and volume expansion after cooking. Rice 11(1):19

Singh VK, Singh A, Singh SP, Ellur RK, Choudhary V, Sarkel S, Singh D, Krishnan SG, Nagarajan M, Vinod KK, Singh UD (2012b) Incorporation of blast resistance into "PRR78", an elite basmati rice restorer line, through marker assisted backcross breeding. Field Crops Res 128:8-16

Singh VK, Singh A, Singh SP, Ellur RK, Singh D, Gopala Krishnan S, Bhowmick PK, Nagarajan M, Vinod KK, Singh UD, Mohapatra T (2013) Marker-assisted simultaneous but stepwise backcross breeding for pyramiding blast resistance genes Piz5 and Pi54 into an elite basmati rice restorer line 'PRR 78'. Plant Breed 132(5):486-495

Singh VK, Singh BD, Kumar A, Maurya S, Krishnan SG, Vinod KK, Singh MP, Ellur RK, Bhowmick PK, Singh AK (2018a) Marker-assisted introgression of Saltol QTL enhances seedling stage salt tolerance in the rice variety "Pusa Basmati 1". Int J of Genomics 2018:1-12

Sood BC, Siddiq EA (1978) A rapid technique for scent determination in rice [India]. Indian J Genet Plant Breeding 38:2268-2271

Tan S, Evans R, Singh B (2006) Herbicidal inhibitors of amino acid biosynthesis and herbicide-tolerant crops. Amino Acids 30(2):195-204

Tan S, Evans RR, Dahmer ML, Singh BK, Shaner DL (2005) Imidazolinone-tolerant crops: history, current status and future. Pest Management Sci: Formerly Pesticide Science 61(3):246-257

Tranel PJ, Wright TR (2002) Resistance of weeds to ALS-inhibiting herbicides: what have we learned? Weed Sci 50(6):700-712

Van Berloo R (1999) Computer note. GGT: software for the display of graphical genotypes. J of Heredity 90(2):328-329

Yu Q, Powles SB (2014) Resistance to AHAS inhibitor herbicides: current understanding. Pest Manag Sci 70(9):1340-1350

Zhou Q, Liu W, Zhang Y, Liu KK (2007) Action mechanisms of acetolactate synthase-inhibiting herbicides. Pest bioc and phys 89(2):89-96

\section{Publisher's Note}

Springer Nature remains neutral with regard to jurisdictional claims in published maps and institutional affiliations.

\section{Submit your manuscript to a SpringerOpen ${ }^{\circ}$ journal and benefit from:}

- Convenient online submission

- Rigorous peer review

- Open access: articles freely available online

- High visibility within the field

- Retaining the copyright to your article

Submit your next manuscript at $\boldsymbol{\sim}$ springeropen.com 